\title{
O POJEZCIU GODNOŚCI NARODOWEJ W POLSKIEJ MYŚLI ROMANTYCZNEJ
}

W spółcześni badacze nacjonalizmu wskazują, że obok znaczących różnic między poszczególnymi ideologiami nacjonalistycznymi można znaleźć pewne wspólne cechy w mniejszym lub większym stopniu reprezentowane przez nacjonalistyczny system przekonań. Wyodrębniają ogólny zestaw podstawowych pojęć, który pomaga określić fundamentalne idee i cele nacjonalizmu. Anthony D. Smith w składzie tego zespołu wyróżnia: przekonanie o autentyczności, ciągłości i przywiązaniu do narodu, wiarę w przeznaczenie wspólnoty oraz pojęcia ojczyzny i zbiorowej godności. Nie wszystkie te składniki są przywotywane przez każdą ideologię czy ruch nacjonalistyczny i nie w tym samym natężeniu. Niemniej stanowią one w miare stały zestaw fenomenów ${ }^{1}$.

Z tak obszernego zespołu problemów wybrano zagadnienie związane z wyobrażeniem godności narodowej w polskiej refleksji pierwszej połowy XIX wieku. Okres poddany analizie wydaje się szczególnie interesujący ze względu na specyficzne warunki kształtowania się ówczesnej polskiej myśli na temat narodu. Odczucia poniżenia, ofiary, niesprawiedliwości, krzywdy wyrządzonej zniewolonemu i prześladowanemu narodowi powszechnie towarzyszyły przynajmniej tej aktywnej, patriotycznie zaangażowanej części społeczeństwa polskiego, co znajdowało niejednokrotnie swój wyraz w publicznych wypowiedziach i dyskusjach. Wszelkie działania antypolskie władz zaborczych traktowano jako wymierzone w prawdziwą wartość na-

Dr hab. Joanna NOWAK jest profesorem w Instytucie Slawistyki PAN. joannanowak67@gmail.com

1 A.D. Smith, Nacjonalizm, Warszawa 2007, tłum. E. Chomicka, s. 45-50. Odmienne zestawy cech retoryki nacjonalistycznej prezentują inni badacze zob. choćby C. Calhoun, Nacjonalizm, tłum. B. Piasecki, Warszawa 2007, s. 13-14. 
rodu, w jego zbiorową godność. Warto jednak zauważyć, że jest to tylko jeden z aspektów zagadnienia, a dyskusja wokół godności narodowej była bardziej złożona i wielopłaszczyznowa.

\section{OGÓLNIE O ROZUMIENIU POJĘCIA}

Na wstępie należałoby wyjaśnić, jak rozumiano pojęcie godności narodowej w polskiej myśli romantycznej. Godność narodowa to w ówczesnym przekonaniu poczucie grupowej wartości i dumy z przynależności do własnego narodu, jego charakteru i przeznaczenia w ludzkości. To wartość niezbywalna, ściśle związana z żywotnością narodowej wspólnoty. Jej zanik jest więc równoznaczny z upadkiem narodu.

Warto podkreślić, iż w związku z tragiczną sytuacją narodu funkcjonującego bez własnego państwa, prawdziwej wartości zniewolonej wspólnoty poszukiwano bardziej W "świetlanej” przeszłości niż w „ponurej”, niedoskonałej teraźniejszości. Wobec braku wolności politycznej i nasilających się po kolejnych powstaniach prześladowań odwoływano się przede wszystkim do przesadnie wyidealizowanych minionych epok. W tym znaczeniu był to rodzaj ucieczki od powszechnie krytykowanej współczesności. Ta fascynacja czasem minionym miała swoje podstawowe źródło w typowym dla romantyzmu zwróceniu się ku historyzmowi, odwołującym się do dziejów wspólnoty i podkreślającym ciągłość narodowej tradycji. Kontekst rozważań obejmował więc nie tylko przestrzeń, ale i kategorię czasu. Naród nie był już pojmowany tylko jako związek ludzi na określonym przez prawo i geografię obszarze (zbiorowość państwowo-terytorialna), jak w dawniejszych koncepcjach oświeceniowych, ale przede wszystkim jako wspólnota w czasie, spójnia przeszłych teraźniejszych i przyszłych pokoleń.

Najistotniejsza była chwalebna historia narodu, kult narodowych bohaterów, sława zwycięstw, pomniki wyjątkowych osiągnięć w różnych dziedzinach nauki i kultury. Nie oznacza to, że romantyczni twórcy żywili przekonanie o całkowitym zaniku poczucia godności w czasach im współczesnych. Na pewno jednak jego utrzymanie wymagało podjęcia celowych zabiegów. Zdaniem ówczesnych myślicieli, poczucie godności w samym narodzie należało nie tyle od nowa stworzyć, ile odbudować, ponownie wzbudzić, bowiem Polacy na wskutek świadomych działań zaborczych stopniowo zatracają poczucie zbiorowej wartości i dumy. Bez niego naród nie przetrwa, nie będzie miał wystarczającego motywu, aby chronić narodową indywidualność. Uznając swoją niedostateczność, znikomość, bierność, stanie się pasywnym i w konsekwencji będzie łatwym łupem dla obcych, zaborczych bytów. Dlatego podstawowym zadaniem polskich elit politycznych i intelektualnych było nieustanne przypominanie społeczności o własnej wartości i umacnianie tego przekonania.

Jak podkreślano, dla dużej części narodu pozbawionej świadomości należało tę wartość dopiero odkryć, przybliżyć im najpiękniejsze karty narodowej historii i pomniki kultury. Innymi słowy, należało poszerzyć zakres społeczny świadomości narodowej, aby poczucie godności towarzyszyło jak największej grupie jednostek we wspólnocie. Tę dumę narodową opartą na przeszłości Polski, co skryła się „pod strzechą w sercach ludu", o której pisał Joachim Lelewel, należy jedynie odsłonić, aby na powrót ta najliczniejsza część narodu przeobraziła się w „ludzi czujących”2. W bardziej pesymistycznym obrazie,

2 J. Lelewel, Lud a przyszłość Polski, [w:] Dzieła, t. 2, Warszawa 1964, s. 881-886. 
na przykład w ujęciu Jana Ludwika Żukowskiego, godność narodową wśród ludu pozbawionego całkowicie świadomości narodowej będzie trzeba nie tyle odsłonić, ile od nowa zbudować.

W kolejnym etapie wytyczonych działań, już uświadamianą przez członków narodowej wspólnoty prawdziwą wartość narodu należało starannie p i el ę g n o wa ć i w sposób zdecydowany bronić. Wszelkie próby odebrania godności narodowej - odarcia z symboli, odebrania historycznych wspomnień i pamiątek, muszą wywołać zdecydowany i natychmiastowy sprzeciw i opór. Stąd też tak niezwykle popularny ruch w kierunku zbieractwa i zachowania narodowego dziedzictwa już od początku okresu niewoli, pielęgnowanie narodowych zwyczajów, języka, kultury zagrożonych wynarodowieniem, w miarę możliwości w warunkach zaborów kultywowanie narodowych obchodów i historycznych rocznic. Szeroko propagowano podobne działania w ówczesnej prasie. W humanistycznych periodykach, a nawet w niektórych dziennikach informacyjnych powstały specjalne działy lub cykle tematyczne, jak np. Pielgrzym z Tęczyna, ukazujący się na łamach „Pszczółki Krakowskiej” a poświęcony historycznym dokonaniom królów polskich, zwyczajom przodków, ich bohaterskim czynom, czy felietony Bywalskiego w "Tygodniku Polskim i Zagranicznym" na temat narodowych i regionalnych zwyczajów. W ówczesnym przekonaniu był to jeden z ważniejszych sposobów rozbudzenia poczucia narodowej świadomości i godności prowadzący do umocnienia własnej narodowej tożsamości. Idea narodowa ma niezaprzeczalne prawo stawiać sobie pomniki, które mają teraźniejszości i przyszłości przypominać przeszłość, a w rezultacie zachowywać "godność i świętość" narodu. Wspólnota, która nie pojmuje już konieczności takich ofiar i pomników, przestałaby być samą sobą, autorytarnie stwierdzał Zygmunt Krasiński³.

\section{O ZWIĄZKU GODNOŚCI, HONORU I RYCERSKOŚCI}

Gdy mowa o bohaterstwie i bohaterach narodowych, z poczuciem godności ściśle łączyło się pojęcie ho noru, które w kontekście zbiorowym postrzegano jako nieodłączny środek prowadzący do obrony narodowej godności. Honor w znaczeniu indywidualnym jest „świętym prawem”, znamieniem godności człowieka. Dlatego nie można, upraszczając to pojęcie, utożsamiać honoru na przykład z ideą pojedynków, która w opinii romantycznie usposobionego S. Buszczyńskiego jest podyktowana wyłącznie modą - to „instytucja barbarzyńska, przynoszącą zakałe postępowi"4. O honorze w podobnym kontekście pisał sto lat wcześniej ksiądz Gwilhelm Kaliński. Dbałość o jego zachowywanie jest przymiotem dobrym, społecznie pożądanym, ale tylko pod warunkiem kierowania się rozumem. Pojedynki niczego nie rozwiązują i nie rozwijają pozytywnych przymiotów takich jak honor, a lekceważenie życia świadczy raczej o braku rozsądku, konkludował5

Zdaniem ówczesnych twórców, zarówno w znaczeniu jednostkowym jak i zbiorowym, pojęcie honoru nierozłącznie wiązało się z cnotą i tylko człowiek postępujący zgodnie z prawami moralnymi czy wspólnota prawdziwie moralna może poszczycić się honorem.

3 List Z. Krasińskiego do Władysława Zamoyskiego, 15 VI 1851, [W:] Jenerał Zamoyski 1804-1868, t. 5, Poznań 1922, s. 371.

4 S. Buszczyński, Upadek Europy, Kraków 1895, s. 177 (pierwsze wydanie książki Buszczyńskiego ukazało się w Paryżu w 1867 roku w języku francuskim pt. La décadence de L'Europe).

5 Zbiór różnych materyj moralnych, tak fragmentów prawa natury, jako i materiałów do kazań, "Wizerunki i roztrząsania naukowe", Rozmaitości, Wilno 1836, tomik 1, s. 147. 
Nie wszystkie wspólnoty i kultury znają te pojęcie. Nie wystarczy bowiem czysta deklaracja, ale następująca w ślad za nią konkretna nienaganna postawa i zachowanie. Henryk Kamieński, pisząc o tej nierozłącznej parze narodowych wartości, honorze i godności, doszedł do wniosku, że w rosyjskich wyobrażeniach nie było nigdy dla nich miejsca. A to dlatego, że w Rosji nie istniała tradycja rycerstwa, z której narody z kręgu cywilizacji łacińskiej czerpią odpowiednie wzorce ${ }^{6}$. W imperium carów mamy do czynienia jedynie z powierzchownym naśladownictwem obcych wzorów, cudzoziemskich wyobrażeń odnośnie do honoru i rycerskości, całkowicie niezrozumiałych dla zdecydowanej większości rosyjskiego społeczeństwa.

Karol Boromeusz Hoffman nieco inaczej oceniał ten problem. Choć w pełni utożsamiał się z poglądem o braku pojęcia honoru i godności, tak jednostkowej jak i zbiorowej w Rosji w rozumieniu zachodnim, to jednak podkreślał, że te abstrakty funkcjonują w narodzie rosyjskim w odmiennej formie. Najdoskonalsi rosyjscy pisarze, najbardziej cywilizowani Rosjanie głoszą sofizmat, że godność człowieka polega na posłuszeństwie jednej osobie, a narody powinny przyjmować jarzmo despotyzmu z "rezygnacją godną ludzi wolnych"7. To odmienne pojmowanie godności powstało więc pod wpływem cech wspólnotowych Rosjan takich, jak choćby: cierpliwość, rezygnacja, ślepe posłuszeństwo władzy oraz specyficznie rozumiany patriotyzm zasadzony na samych ujemnych skłonnościach natury ludzkiej czyli fanatyzmie religijnym i nienawiści przeciw innym ludom inaczej zorganizowanym niż Rosja. W opinii K.B. Hoffmana tak rozwija się cywilizacja Rosji także w czasach współczesnych, a jej duch jest biegunowo przeciwny duchowi cywilizacji zachodniej.

Podobnie zresztą jak w kulturze tureckiej, gdzie zachowania i ideały rycerskie powszechnie znane w Europie były dla Turków obce, niezrozumiałe i w ich odczuciu barbarzyńskie ${ }^{8}$. Jak podkreślał romantyczny orientalista Józef Sękowski, w języku tureckim nie ma nawet słownych odpowiedników na wyrażenie pojęć miłości ojczyzny i honoru. Są to wyobrażenia zachodniej cywilizacji: pierwsze zaczerpnięto z języka łacińskiego, drugie zaś pochodzi od idei "błędnego rycerstwa" 9 .

W rozumieniu zachodnioeuropejskim człowiek honorowy, podobnie jak cały naród, myśli i czuje z wrodzoną sobie szlachetnością. W postępowaniu kieruje się cnotą, moralnością i odwagą. Za francuskim encyklopedystą, pisarzem i moralistą Charles'em Pinot Duclos powtarzano, że „honor instynktem jest niejako cnoty i stanowi jej odwage. Nie roztrząsa on; działa bez zmyślenia, nawet bez ostrożności i nie zna owej bojaźni lub fałszywego wstydu"10. Co więcej, honor jest przymiotem przyrodzonym, jednak rozwija się poprzez edukację i wzmacnia za sprawą przywoływanych chwalebnych przykładów z przeszłości narodu. Dla romantycznych twórców godność i honor były więc d z i e d z i c z o n e po cieszących się wolnością, a wywodzących się z rycerstwa, przodkach.

Pojęcia te nie mogły natomiast zaistnieć w umysłowości narodu w warunkach odwiecznej przemocy, kultu siły, całkowitego braku wolności. Takie wspólnoty jak Rosja czy Turcja

6 Nie była to oryginalna teza Kamieńskiego, ale stanowisko przyjęte za A. De Custinem. H. Kamieński, Rosja i Europa. Polska, Warszawa 1999, s. 220-221. Por. A. markiz De Custine, Listy z Rosji, przekład z franc. M. Górski, M. Leśniewska, Warszawa 1991, s. 20-21. „Rosjanie są wojownikami, ale dla zdobywania, walczą z posłuszeństwa i chciwości, podczas gdy rycerze polscy wojowali wyłącznie z miłości sprawy". Tamże, s. $18-19$.

7 K.B. Hoffman, O Panslawizmie zachodnim. Studium historyczne, Poznań 1868, s. 6-8. Autor przytacza m. in. uwagi N. Karamzina na temat umystowości Rosjan.

8 J.J.S. Sękowski, Collectanea z Dziejopisów Tureckich. Rzeczy do Historyi Polskiey służących, Warszawa 1824 , t. 1, s. 35.

9 Tamże, t. 2, s. 172

10 O poczciwości, cnocie i honorze (z Duclosa) przez S. K. "Pamiętnik Umiejętności Moralnych i Literatury”, Warszawa 1830, t. 4, s. 166. 
zamiast honoru i godności mają co najwyżej do czynienia z parodią tych wartości, wyrosłą na złych fundamentach: na całkowitym poniżeniu, bezwzględnym posłuszeństwie, wybujałej pysze czy religijnym fanatyzmie. Nie można budować narodowej godności wyłącznie na obcych wzorcach, jeśli nie są one zakorzenione w narodzie. Chodzi o coś więcej gdyż: „nie oręż przy boku, nie stalowa zbroja, nie rumak żelazem pokryty stanowiły rycerza, lecz jego duch - lecz nade wszystko umyst hardy i niezawisły, pychy nad sobą nie znoszący"11.

Naród polski nie tylko jako członek, ale i obrońca cywilizacji łacińskiej zawsze w pełni należał do grupy ludów i narodów pielęgnujących narodową godność i honor w oparciu o dawny ideał rycerski. W stosunkach zewnętrznych ta godność objawia się w poszanowaniu wolnościowych praw i godności innych wspólnot. Konstanty Bobrownicki uzasadniał tę przynależność polskiego narodu do "ludów chwały”, posługując się argumentem nieszkodzenia sąsiadom, nieanektowania ich terytorium, własności, a jeśli nawet Polacy wkroczyli na cudze ziemie, to tylko w celach obronnych ${ }^{12}$. Natomiast wspólnoty same pozbawione godności nie potrafią uszanować jej u innych narodów. Dlatego zawsze krzywdzą i poniżają słabsze byty. Co więcej, jest to działanie świadome, konieczny element polityki wynaradawiającej, gdyż naród, któremu odebrano godność, traci poczucie własnej wartości, chęć do dalszego podtrzymywania narodowych wzorców, a w konsekwencji odrębną tożsamość. Jak podkreślał Aleksander Fredro, to właśnie Polacy posunęli dawną szlachetność rycerską do granic możliwości, co uwidaczniało się najwyraźniej w ich stosunku do nieprzyjaciela. „Dla Polaka zwyciężony i bezbronny jest świętą i nietykalną osobą. Zaledwie pierwszy zapał ostygnie, dzieli się żywnością, odzieżą, pieniędzmi wypiłby z nim "kochajmy się» byle było czym". Podczas gdy na przykład Francuzów w podobnej sytuacji cechuje egoizm, a Prusaków zemsta i podłośćn ${ }^{3}$.

W ujęciu Józefa Ordęgi początkowo stan rycerski nie był uprzywilejowany. „Imię to wyobrażało raczej obowiązek tylko dla niego przywiązany, to jest obowiązek walczenia z bronią w ręku za cel narodowy"14. Dopiero w okresie późniejszym nastąpiło odejście od tej zasady. Innymi słowy, nie status urodzenia, pozycja społeczna i majątkowa, ale poświęce nie się dla ojczyzny stanowi o wartości każdego członka w zbiorowości. I tylko osoba myśląca $w$ tym duchu i realizująca narodowe ideały zdolna jest prawdziwie odczuwać zbiorową godność. Romantyczni twórcy poczucie godności narodowej uzależniali więc od stanu patriotyzmu we wspólnocie, doznania, które jest „cząstką boskiego płomienia" ożywiającego i spajającego ducha określonej wspólnoty. Nie tyle sukcesja pozostałych po przodkach ziem i krain tworzy patriotyzm i daje poczucie godności, ile wznioślejsze dziedzictwo wszystkich umysłowych zdobyczy, wszystkich najwznioślejszych uczuć i myśli, które zagrzewały przodków, torowały im drogę do sławy i znaczenia. W tym kontekście patriotą jest ten, który odziedziczywszy cały ten zasób umysłowych przymiotów narodu, "nim oddycha i w nim żyje. Zrzeka się wszystkiego co posiada byleby spełnić mógł co mu przeznaczenie narodu nakazuje". Należy więc działać tak jak to robili przodkowie narodu w najwznioślejszych chwilach. Jedyną zasadą patriotyzmu - istotą narodowego bohaterstwa i honoru jest więc całkowite poświęcenie się dla swego ludu/narodu. Naród polski jest patriotyczny i pielęgnuje narodową godność, gdyż potrafi dziedzictwo przodków nie tylko trwale zachować, ale gotów jest dla niego wszystko poświęcićc ${ }^{15}$.

11 H. Kamieński, dz. cyt., s. 221

12 Wiersz do Aleksandra I, Cesarza Wszech Rosji przez oficera polskiego napisany W roku 1814, „Pszczółka Krakowska" pod red. K. Majeranowskiego, t. 2, Kraków 1820, nr 37, s. 39.

13 A. Fredro, Trzy po trzy, opracowała E. Zarych, Kraków 2004, s. 29, 39.

14 J. Ordęga, O narodowości polskiej z punktu widzenia katolicyzmu i postępu, Paryż 1840, s. 80.

15 Patriotyzm, „Zjednoczenie. Dziennik narodowości poświęcony”, 1831, nr 8, z dnia 8 lipca, s. 32. 
Poczucie narodowej godności opierano na konkretnym wzorcu nawiązującym do najdawniejszej, mitologizowanej przeszłości. Warto podkreślić, że nie był to ideał o wyłącznie zachodniej proweniencji, odwołujący się do wywodzącego się ze średniowiecznej kultury europejskiej wzoru rycerskości. Często powoływano się na własne, odrębne tradycje pradawnych Sarmatów, ich charakter i obyczaje, które uczyniono podstawą rodzimego rycerskiego ethosu. Naród polski odziedziczył więc po sarmackich protoplastach odwagę, waleczność, dumę, honor, bezinteresowne umiłowanie ojczyzny. Zdaniem jednego z ówczesnych publicystów powinniśmy być dumni z narodu, który w ogólnym rozrachunku był „wyższy od Rzymian” słynących przecież z patriotyzmu i męstwa. Naród polski, ten spadkobierca sarmackich cnót, nigdy nie anektował obcym rodzinnych siedlisk, jak to czynili Rzymianie ${ }^{16}$. Co więcej, rycerski ethos i brak egoizmu pozwolił Polakom przez wiele wieków pełnić zaszczytną rolę obrońców chrześcijaństwa i cywilizacji łacińskiej przed barbarzyństwem. Tak stopniowo wyrabiało się poczucie narodowej godności opartej na honorze, bohaterstwie, idei równości i braterstwa między narodami.

W warunkach zaborów rycerski ethos odegrał więc znaczącą rolę przy kultywowaniu zbiorowej godności, gdy "poszukiwanie chwały” stało się obowiązkową powinnością świadomej narodowo części społeczeństwa polskiego. Ten stan szczególnego utrzymywania się ethosu rycerskiego w Polsce zachował się długo, choć, jak podkreśla Maria Ossowska w zdeformowanej postaci, pielęgnowany zwłaszcza przez zubożałą szlachtę. Nie miała ona innych powodów do dumy, jak zasługi przodków i wierność sprawie narodowej ${ }^{17}$. Poczucie narodowej godności w języku romantycznych twórców to właśnie „żądza narodowej sławy” lub po prostu „miłość ojczyzny"18.

Apologeci szlacheckiej przeszłości kreowali konkretny wzorzec osobowy do naśladowania, wyidealizowany portret bohaterskiego szlachcica, żarliwego patrioty bezgranicznie poświęcającego się dla narodu, wręcz męczennika za ojczyznę. Wzorzec idealny takiego bohatera związany był nierozłącznie z czynem rycerskim opierającym się na micie sarmackim, a więc z jednej strony na poczuciu dumy z przynależności do elity społecznej, z drugiej zaś na wynikających z niej obowiązkach dla dobra wspólnoty. Obok honoru, odwagi i poświęcenia wykreowany ideał musiał spełniać wysokie wymogi moralne, szanować tradycję i szlacheckie obyczaje oraz respektować indywidualne prawa jednostki (w oparciu o idee tolerancji dla różnorodności). Taki wzorzec osobowy miał stać na straży narodowej godności, strzegąc wspólnotę przed poniżeniem, a w dalszej konsekwencji upadkiem. Dla jednego z gorliwych apologetów szlachetczyzny, Henryka Rzewuskiego, takim idealnym wzorem do naśladowania, symbolem narodowej godności był „pełen wiary i pokory” Tadeusz Rejtan, wzorowy obywatel, społecznik, patriota, bohater, wierny tradycji szlacheckiej, a ostatecznie męczennik za wolność i jedność ojczyzny. Jak patetycznie prognozował autor Pamiątek Soplicy, „co wiara ma najświętszego w swoich obrządkach, co rozsądek narodu może wynaleźć najokazalszego w wyświadczeniu ogólnych uczuć, złączą się, by uwiecznić pamięć naszego bohatera"19.

\section{$\cdots \cdots \cdots$}

16 Listy do Wandy o mistycznych dziejach Narodu Polskiego przez S. Jaszowskiego "Pszczółka Krakowska”, t. 1, Kraków 1821, s. 109-113.

17 M. Ossowska, Ethos rycerski i jego odmiany, Warszawa 1973.

18 K. Libelt, O mitości ojczyzny, Poznań 1847, rozdział 7, s. 51.

19 H. Rzewuski, Pamiątki Soplicy, oprac. K. Duda Kaptur, Kraków 2009, s. 115-125. 
W opinii romantycznych twórców zagrożenia dla zachowania poczucia godności narodowej były dwojakiej natury: zewnętrznej i wewnętrznej. W pierwszym przypadku chodziło o niebezpieczeństwa czyhające ze strony obcych państw, które podejmując celowe działania w kierunku całkowitego zniewolenia podległych im narodów, systematycznie niszczyły wszelkie przejawy narodowej dumy i godności. Rozważania na ten temat stawały się intensywniejsze w momentach przełomowych, choćby przy okazji powstań czy nasilania się represji stosowanych przez władze zaborcze. W okresie powstania listopadowego o zagrożonym poczuciu godności dyskutowano zwłaszcza w kontekście ewentualnej kapitulacji. Zastanawiano się nad kwestią, czy poddanie się będzie jednoznaczne z poniżeniem wspólnoty i upadkiem zbiorowej godności. I w tym przedmiocie zdania były podzielone. Dla autorów o poglądach zachowawczych podjęcie układów z Rosjanami to jedyne rozsądne wyjście z tragicznej sytuacji - próba uratowania resztek narodowych znamion bez szkody dla zbiorowego poczucia honoru i godności. W ujęciu bardziej radykalnie nastrojonych patriotów, przeciwnie. „Amnestia”, pisał we wrześniu 1831 roku na łamach „Dziennika Narodowego" Maurycy Mochnacki, „byłaby pieczęcią wiecznej hańby, wytłoczoną na grobie ojczyzny" 20 .

$\mathrm{Na}$ łamach krajowych periodyków rewolucyjno-demokratycznych podtrzymywano pogląd, iż wszelkie układy z Rosją są równoznaczne z rezygnacją z niepodległości, narodowości, honoru, z dobrowoln y m wyrzeczeniem się godności. Nie powinno się negocjować kapitulacji z wrogiem, a Polacy przegrywając militarną i polityczną batalię, zdołają ocalić przynajmniej honor. „Niech raczej przykryje nas ziemia, niech bezbożny zwycięzca napotyka tylko kości nasze, ruiny miast i wsi, zniszczone niwy, ale niech ma, okropne dlań przekonanie, że Polska nie umie znieważać sama siebie, nie umie sama rzucać klątwy na swoją wolność, na swoją niepodległość". W tym rozumieniu, już przez samo podjęcie układów z nieprzyjacielem własnego narodu obraża się imię przodków, którzy pozostawili Polakom „pamięć wolności”. Walka o nią powinna być bez skazy, wielka i heroiczna, gdyż naród, który sam nie skala własnej godności wzywa olbrzymie moralne siły, które może wykorzystać w obronnej walce. W takiej sytuacji nawet przegrana batalia jest stanem tymczasowym. Zwycięzca nie wyrwie Polakom wolności, "nie wyrwie honoru, bo honor tylko sam człowiek, tylko sam naród może splamić" ${ }^{21}$. Stąd nieuchronny wniosek, że kto dąży do układów z Rosją, obraża honor i godność Polaków, jest zatem zdrajcą ojczyzny.

W tym podejściu alternatywa przedstawiała się następująco: albo układy, a wraz z nimi niewola i utrata honoru, albo zachowanie honoru i narodowej godności, co w dalszej perspektywie pomoże w przetrwaniu i podjęciu kolejnych prób przywrócenia wolności. Układy to pohańbienie własnej ojczyzny. Argumentowano, że poprzez dobrowolne porozumienie z zaborcą Polacy przyznają przed całym światem, że panowanie Rosji na ziemiach polskich jest prawnie uzasadnione. To tak jakby samemu uznać zbrodnię zaborów i zrezygnować z bycia odrębnym narodem. Nadrzędnym celem stało się więc ocalenie honoru Polski i obrona zagrożonej godności narodu. Ten warunek czynit jednak wszelkie układy czymś niepodobnym. Wykraczając nieco poza zakres chronologiczny artykułu, warto podkreślić, iż podobne dyskusje i oceny pojawiły się w związku z kolejnym przegranym

20 Niepodobieństwo układów z Moskwą, [w:] Pisma krytyczne i polityczne, wybór i oprac. J. Kubiak, E. Nowicka, Z. Przychodniak, Kraków 1996, t. 2, s. 94. Mochnacki w okresie powstania radykat, współzałożyciel Towarzystwa Patriotycznego i jeden z czołowych reprezentantów lewicowej opozycji, na emigracji przeszedł na pozycje zachowawcze wiążąc się nieformalnie z obozem ks. A.J. Czartoryskiego.

21 Układy-Zwycięstwa "Nowa Polska”, Warszawa 1831, nr 97, 12 kwietnia, s. 1-3. 
powstaniem (1863). Z jednej strony, silnie zaznaczona rezygnacja z idei walki zbrojnej jako nierealnej i wysoce szkodliwej dla przetrwania narodu, z drugiej natomiast przekonanie, że mimo kolejnej klęski godność narodowa pozostała nienaruszona. „Zostaliśmy pokonani, ale nie upadliśmy, i dlatego w oczach świata nie będziemy poniżeni. Mamy oręż, którego żadnej sile sobie wydrzeć nie damy; tym jest duch narodowy"22.

Wiele pisano o drastycznych przejawach łamania godności narodowej przez władze zaborcze w Królestwie Polskim i skutkach poniżających aktów przemocy, zwłaszcza w okresie powstania listopadowego, gdy swoboda wypowiedzi nie była ograniczona rosyjską cenzurą. O gwałceniu przez Rosjan godności narodowej Polaków przed 29 listopada 1830 roku pisał na przykład Kazimierz Brodziński, wskazując tym samym na istotną przyczynę wybuchu powstania. Akty poniżenia objęły wojskowych, których pozbawiono podstawowych praw (choćby poprzez wprowadzenie nowego regulaminu dopuszczającego kary cielesne) i upokarzano obraźliwym zachowaniem przede wszystkim księcia Konstantego. Co więcej, było to działanie celowe, gdyż w sposób zamierzony próbowano stłumić w polskich oficerach „uczucie wszelkiej rycerskiej godności”, karząc za typowe dla europejskiej kultury przejawy rycerskiego ethosu ${ }^{23}$. Upokorzenia dotknęły w podobnym stopniu ludność cywilną - przedstawicieli władz Królestwa Polskiego, czy też zwykłych obywateli. Wielokierunkowe działania w celu odebrania zbiorowej godności stały się powodem masowej apatii, nieufności, zniechęcenia i rozpaczy. „Wszyscy, podejrzani tyraństwu, staliśmy się wzajem sobie podejrzanymi. Żalący się był prowokatorem, milczący szpiegiem. Lękając się podejrzliwych, baliśmy się obcować z podejrzanymi... Zagęściły się nie znane w narodzie samobójstwa; nienawiść młodych pokoleń ze starymi, rozpaczających z płaczącymi, wojska z ludem, urzędnika z obywatelem. Ledwo naród sam sobą nie zaczął się brzydzić" 24 . Ostatecznie jednak próby odebrania zagrożonej godności wspólnocie o wielowiekowej tradycji zakończyły się niepowodzeniem. Po upadku powstania w warunkach represji na niespotykaną dotąd skalę, dyskusje w tym przedmiocie toczyły się na wychodźstwie. Jak argumentowano w emigracyjnych dyskusjach, wymiernym dowodem na przetrwanie narodowej dumy i godności był właśnie powstańczy zryw narodu o przywrócenie praw wolnościowych i zachowanie zbiorowej tożsamości.

\section{PROBLEMY WEWNĘTRZNE}

Godność narodu mogła być zagrożona nie tylko ze strony czynników zewnętrznych, ale także w wyniku duchowych procesów zachodzących wewnątrz wspólnoty. Dostrzegano różne przyczyny tego stanu rzeczy. Dzieje się tak w sytuacji, gdy zbiorowa duma wskutek różnych pobudek przeradza się w zbiorową pychę. A wtedy, twierdził Cyprian Kamil Norwid, własna ocena przestaje być trzeźwą czy to w wymiarze życia materialnego, czy w sferze umystowej i moralnej. Duma była więc postrzegana pozytywnie - to uczucie słuszne, szlachetne i konieczne dla zaistnienia narodowej godności, podczas gdy pychę uważano za zgubną, pustą, pozbawioną umoralniających społeczność obowiązków²5.

22 S. Buszczyński, Obrona spotwarzonego narodu, Kraków 1888, zeszyt 1, s. 108. Buszczyński uważat, że powstania 1863 nie należy oceniać w charakterze błędu politycznego, szału czy lekkomyślności. To było "nieuniknione następstwo zdarzeń, wypływających z przemocy", okrucieństwa zaborców, poniżania narodu.

23 K. Brodziński, O narodowości Polaków, czytano na sesji Towarzystwa Przyjaciół Nauk 3 maja 1831, [w:] Idee programowe romantyków polskich. Antologia, oprac. A. Kowalczykowa, Wrocław 2000, s. 204.

24 K. Brodziński, dz. cyt., s. 205.

25 C.K. Norwid, Pisma polityczne i filozoficzne, oprac. Z. Przesmycki, Londyn 1957, s. 202-205. 
Pycha jest więc zniekształceniem narodowej dumy i godności. Innymi słowy, dumę wiązano z patriotyzmem, a pychę z szowinizmem, który wówczas określano bardziej opisowymi terminami takimi, jak: „wybujała duma”, „nadmierna miłość narodu”, czy wręcz "zboczenie miłości”. O takim nadmiernym „ubóstwieniu narodowości” pisał anonimowy autor książki Sprawy włoskie w związku z teraźniejszością. Najgorsze jest zbytnie wynoszenie się ponad inne narody zamiast trzeźwego i wyważonego przekonania o własnej wartości. „Duma narodowa wysoko wybujała” jest wyrazem spaczenia w postrzeganiu własnego narodu i jego miejsca w świecie społecznym ${ }^{26}$. Jest to postawa dla wielu wspólnot kusząca, zwłaszcza dla narodów zniewolonych, którym próbuje się odebrać narodową godność, a przez to wysoce niebezpieczna. Miłość ojczyzny, w tym dbanie o godność narodową należy traktować jako zaszczytny obowiązek, a nie rodzaj religii. J.J. Sękowski podkreślał, że w Polsce dużo się jeszcze ukrywa „pod maską źle zrozumianej narodowości, pod którą najczęściej tai się zgubne niepobłażanie dla tego wszystkiego, cokolwiek dąży do odkrycia wad charakteru narodowego" 27 . W ten sposób nie buduje się poczucia narodowej godności. Należy uświadomić sobie narodowe wady, w sposób wyraźny napiętnować wszelkie ułomności, gdyż tylko w ten sposób można z nimi walczyć.

Naród godny odczuwa dumę z posiadanych cnót i wartości, ale jednocześnie zna swoje słabe strony, jest otwarty na krytykę. Przykładem wspólnoty, w której zamiast zbiorowej dumy panoszyła się pycha i pogarda dla innych, była XVII-wieczna Hiszpania. "Nadęty Hiszpan arogancją i pychą, wyłączał się od reszty ludzi, w surowej powadze, z męską flegmą do jakowejś wielkości zdawał się piąć", pisał J. Lelewel. Przyczynę tego stanu rzeczy upatrywał w nieprawidłowym rozwoju wewnętrznym kraju i narodu, w tym przede wszystkim w absolutyzmie monarszym i nadmiernym uprzywilejowaniu duchowieństwa (indeksy, zakazy, cenzura, inkwizycja). Te obostrzenia i prześladowania niszczyły wyższe uczucia i zdolności, niszczyły narodową godność. Zanikło zacne poczucie zbiorowego interesu zastąpione postawą egoistyczną, a Hiszpanie politycznie i moralnie upodleni, wyrzekli się dumy, prawości i cnót publicznych ${ }^{28}$.

$\mathrm{Na}$ drugim biegunie wewnętrznych zagrożeń dostrzegano powszechne zobojętnienie wobec kwestii narodowych prowadzące do stopniowego zatracenia ducha narodu. Godność zbiorowa, zaniedbywana, z czasem zamiera w sposób naturalny, nawet bez udziału czynników zewnętrznych. Dzieje się tak wówczas, gdy członkowie wspólnoty przyjmują egoistyczną postawę dbania jedynie o własną pozycję, doczesne przyjemności, kosztem spraw wyższych, w tym i narodowych. O takim zagrożeniu pisał choćby Julian Ursyn Niemcewicz, z oburzeniem wspominając huczne bale, przyjęcia, biesiady urządzane przez polską elitę towarzyską i młodzież w karnawale 1830 roku. Postawa "samolubstwa i obojętności względem zgwałceń najświętszych praw naszych" osiągnęła taki poziom, iż codziennie wyrządzane zniewagi ze strony władz zaborczych mało kogo obchodziły ${ }^{29}$. Godność narodowa wobec takiego zobojętnienia została w poważnym stopniu zagrożona.

Poczucie godności wspólnotowej jak i jednostkowej może także ulec osłabieniu, gdy materia odniesie zwycięstwo nad duchem. Stałym motywem romantycznej refleksji w tym przedmiocie była krytyka współczesnego świata, gdzie, jak podkreślano, dążność do zaspokajania doczesnych potrzeb rządzi niepodzielnie. Ludzie stali się "machinami ra-

26 Sprawy włoskie w związku z teraźniejszością, Lipsk 1848, s. 85-86.

27 J.J.S. Sękowski, Collectanea z Dziejopisów Tureckich. Rzeczy do Historyi Polskiey stużących, Warszawa 1824 , t. 2, s. $5,6$.

28 J. Lelewel, Historyczna paralela Hiszpanii z Polską w wieku XVI, XVII, XVIII, Poznań 1845, s. 21-26.

29 J.U. Niemcewicz, Pamiętniki z 1830-1831, Kraków 1909, wydał M.A. Kurpiel, t. 1, s. 7. 
chunkowymi", zatracając człowieczeństwo, konstatował Józef Ignacy Kraszewskiº. Starania o dobrobyt nie odrodzą narodów moralnie. To kierunek na pozór najrozumniejszy, ale przez poświęcenie się materialnemu zyskowi kosztem duchowego rozwoju poniżający człowieka, a w konsekwencji odbierający mu godność. W tym ujęciu pojęcie godności ściśle związane było ze sferą duchową, a tam gdzie rządzi interes czysto materialny, tam duch musi ulec zatraceniu.

Nie tylko nadmierne bogacenie się, czy szerzej uleganie materializmowi niszczy narodową godność, ale także ciężkie warunki bytowe i brak jakichkolwiek perspektyw na poprawę losu. Poniżana, żyjąca w nędzy grupa społeczna wewnątrz wspólnoty, pozbawiona należnych jej praw, nie jest zdolna do wyższych odczuć. Obowiązkiem czynnej i świadomej elity narodu jest więc dążenie do zlikwidowania powstałych barier i nierówności społecznych i stopniowe przywracanie świadomości oraz poczucia zbiorowej wartości. Lud, który stanie się właścicielem ziemi i otrzyma polityczne uprawnienia przez nowy stan rzeczy nie tylko polepszy swój stan ekonomiczny, ale i moralny, „wynajdzie siły, pokaże męstwo, którego nie złamią najezdne wojska" ${ }^{31}$. Bez takiej reformy ta najliczniejsza, a poniżana grupa w narodzie nie odczuje godności jednostkowej czy zbiorowej. W tym kontekście pojęcie godności narodowej pozostaje w sprzeczności z egoistyczną postawą klas uprzywilejowanych, które dążąc do utrzymania swojej pozycji, celowo wykluczają znaczącą część narodu z narodowej wspólnoty. Nie może być mowy o poczuciu godności zbiorowej w przypadku, gdy gwałcone są podstawowe normy społeczne i moralne.

Społeczny zakres poczucia godności zależy więc od konkretnych zabiegów podejmowanych wewnątrz narodu. Karol Libelt w pracy Pomysty o wychowaniu ludów twierdzit, iż „lud i ród ludzki uszlachetnia się, gdy się w masach pojęcie godności jego, a zatem godności człowieka w ogólności wyrabia". W praktycznym wymiarze to uszlachcenie ludzkości dokonuje się poprzez oświe ce nie najlepiej - odwołując się do wskazań C.H. de Saint Simona - dzięki masowemu kształceniu w narodowych szkołach publicznych. Naturalnie nie chodzi o samą znajomość rzeczy, bo wiedza naukowa jest domeną pojedynczych ludzi a nie całych narodów, ale o stopniowe wyrobienie się godności człowieka. Uczoność jest rzemiosłem, zatrudnieniem, powołaniem, stanem, zatem nie można ludu uczynić uczonym w całości. Pedagogika ludów polega na rozwijaniu nauki, religii, prawa i historii. W ten sposób społeczność wykształci w sobie poczucie zbiorowej godności32. Oś wiata podnosi więc godność człowieka, a "kto ją uczuł w sobie, nie ugnie karku pod jarzmo, ani nie nadstawi grzbietu, z którego by satrapa jaki konia dosiadat". Dzięki rozwinięciu godności w narodzie wykształca się postępowa opinia publiczna, która staje się wielką siłą, moralną opoką, o którą rozbijają się wszelkie nadużycia władz i zamachy na wolnośćc ${ }^{3}$. Godność narodowa jest więc ściśle związana z procesami demokratyza c ji życia społecznego.

W podobnym duchu wypowiadał się Edward Dembowski, w ujęciu którego to „zamiłowanie umnictwa (a tym bardziej działanie w jego dziedzinie) rodzi samowiedzę godności własnej, bo kto widzi, co duch ludzki stworzył, uczci tego ducha, pozna jego potęgę i sam moc stwarzania w sobie uczuje" ${ }^{34}$. Z poczuciem godności ściśle wiąże się także pojęcie odwagi cywilnej. Tam, gdzie nie doszło do jej rozwinięcia, wnosić należy, że lud żyje w ciemnocie, pozostając w poniżeniu moralnym i obyczajowym. Despotyzmu nie da się

30 J. I. Kraszewski, Choroby wieku, Wilno 1857, s. 24-26.

31 W. Zwierkowski, Chłop i szlachcic, "Nowa Polska”, półarkusz 20 i 21, z dnia 10 marca 1835, s. 317-320.

32 K. Libelt, Pomysty o wychowaniu ludów, [w:] Rozprawy, Kraków 1869, s. 166, 196.

33 K. Libelt, O miłości ojczyzny, [w:] Rozprawy, Kraków 1869, s. 86.

34 E. Dembowski, Pisma spoteczne i polityczne, wybór i wstęp Jerzego Ładyki, Warszawa 1979, s. 44. 
pogodzić z oświeceniem i moralnym bytem narodu, a odwaga z niewolą. G o d n o ść pojedynczego człowieka czy całych wspólnot łączono więc z ideą wolności. Na przeciwległym biegunie mamy natomiast azjatycki despotyzm oparty na antydemokratycznych zasadach, gdzie pojęcie godności nie występuje ${ }^{35}$.

W pierwszej połowie XIX wieku, podobnie jak i współcześnie, dostrzegano istniejącą ścisłą korelację pomiędzy godnością indywidualną a zbiorową. Począwszy od czasów rewolucji francuskiej za moralny fundament praw człowieka uznawano jego godność osobistą opartą na przekonaniu o wyjątkowości człowieka zdolnego do myślenia, wyższych uczuć, różnorodnej twórczości, niezależnie od urodzenia, pozycji społecznej czy majątkowej. Godność osobista, którą można rozpatrywać z perspektywy filozoficznej, historycznej, psychologicznej, prawnej czy religijnej, jest z kolei podstawą godności zbiorowej - narodowej, grupowej, zawodowej itp. Godność przejawia się wtedy, gdy jednostka lub zbiorowość realizują pewne dobra w różnych aspektach życia społecznego ${ }^{36}$.

Steve Fenton, współczesny badacz zagadnień związanych z etnicznością, opisuje tę relację (między godnością jednostkową a zbiorową) na przykładzie upośledzonych społecznie grup etnicznych, gdy przyjęte nierówne traktowanie członków tych grup oznacza, że afront jakiego doznają jednostki skierowany jest nie tylko do nich samych, ale także do całej zbiorowości. Można wówczas albo zidentyfikować się z nią i walczyć, albo odciąć się od niej, aby uniknąć konsekwencji negatywnego nastawienia względem grupy ${ }^{37}$.

W polskiej refleksji powstatej w warunkach narodowej niewoli większość pojedynczych aktów przemocy i poniżenia członków wspólnoty traktowano jednoznacznie, jako przejaw niszczenia godności nie tylko jednostkowej, ale i zbiorowej. W romantycznym przekonaniu w świecie pojęć obowiązywał ścisły, hierarchiczny porządek: jednostki żyły dla narodów, a te z kolei wypełniały swoje zadania dla dobra ludzkości. W ujęciu Bronisława Trentowskiego dopiero w czasach nowszych doszło do wyrobienia się "pojedynku”, czyli indywidualności. Jeśli chcę, żeby mnie szanowano, muszę dostrzec w drugim osobniku tę samą godność człowieczą, uznać, że drugi człowiek czy cały naród jest mi/nam równy. Każda indywidualność pochodzi z ludzkości, jest jej członkiem i stąd płyną jego obowiązki. Te same zasady obowiązują narody, które mają te same względem siebie powinności, a zatem muszą się szanować, wzajemnie uznawać swoją godność38.

Identyfikowano się więc z próbami indywidualnego pogwałcenia godności, rozciągając je na całą zbiorowość. Poniżanie czy prześladowanie jednostki czy pewnej grupy były równoznaczne z zamachem na godność narodową Polaków. Były natomiast przypadki odcięcia się patriotycznej większości od pojedynczych aktów terroru (np. zamachu na cara Aleksandra II w Paryżu w 1867 roku), które w powszechnej opinii nie licowały z honorem Polaka, jak również od poszczególnych obozów politycznych czy pojedynczych osób w reakcji na konkretne wydarzenia czy głoszone poglądy. Można przy tej okazji wspomnieć

35 K. Libelt, O odwadze cywilnej, [w:] Rozprawy, Kraków 1869, s. 47, 48.

36 Z. Chlewiński, Z. Zaleski, Godność, [w:] Encyklopedia Katolicka, t. 5, Lublin 1989; o rozumieniu pojęcia godności ludzkiej w kontekście filozoficznym, psychologicznym, prawnym i religijnym zob. J. Pazgan, Godność, wolność i prawa człowieka „Perspectiva. Legnickie Studia Teologiczno-Historyczne”, Rok III 2004 nr 1, s. 109-116.

37 S. Fenton. Etniczność, tłum. E. Chomicka, Warszawa 2007, s. 218.

38 B. Trentowski, Mowa w Amfiteatrze Nowodworskim, "Jutrzenka" nr 17 z dnia 10 kwietnia 1848, s. 68. 
o zdecydowanym odcięciu się działaczy obozu zachowawczego na emigracji od działań i poglądów ugrupowań związanych z europejskim węglarstwem. W większości potępiano sposoby działań radykalniejszych ugrupowań, np. Giuseppe Mazziniego - i jego metod "sztyletu i trucizny", które w rezultacie, jako niemoralne prowadzą do upadku godności narodu. "Zabójstwo więc czy partykularne, czy narodowe na nic nie pomaga duchowi", przekonywał Juliusz Słowacki - „duchy bowiem, którym ty formy kruszysz, obciążą ciebie - a w ciałach staną i będą walczyć przeciwko tobie, zająwszy stanowisko lepsze, bo w tym pojedynku i boju ty będziesz przeciw sprawiedliwości ... i niby bojownik słońce boże w oczach bijące tobie będzie szkodziło"39. W politycznym wymiarze, w kręgach zachowawczych, pokładających nadzieję na niepodległość Polski w pomocy rządów mocarstw zachodnich, obawiano się, że sprawa polska może być kojarzona z siłami, które dążą do obalenia istniejącego porządku. Należało więc w sposób zdecydowany odciąć się od podobnych postaw i opcji, aby uniknąć konsekwencji utożsamiania Polaków z radykalnymi rozwiązaniami i rewolucją społeczną. Powszechnie potępiano także postawę i głoszone poglądy tzw. narodowych apostatów, jak choćby Adama Gurowskiego czy Henryka Rzewuskiego, traktując je jako działanie skrajnie szkodliwe dla narodowej godności.

Zatem poczucie własnej godności i towarzysząca jej duma są dwiema własnościami charakteru, zarówno w wymiarze jednostkowym (charakter człowieka), jak i zbiorowym (charakter narodu), stykającymi się ze sobą. Na pozór zdają się wychodzić z jednego punktu, ale mogą stać się wadą lub też rękojmią prawdziwej wielkości, czyli cnotą. W pierwszym przypadku mamy do czynienia z nadmierną dumą pochodzącą z zarozumiałości, a w drugim przypadku ze szlachetnym uczuciem, które ściśle łączy z poczuciem własnej godności. Pyszny człowiek czy pyszny naród siebie ceni wyżej nad wszystkich, a czujący własną godność nikogo nie stawia wyżej nad siebie. W konsekwencji pyszny człowiek/naród poniża drugich, gdyż w każdym widzi wroga, nienawidzi i lęka się współubiegających. Natomiast czujący własną godność, ufny we własne siły nie lęka się współzawodników, a ceni ich jak towarzyszy trudów i podaje ręke upadającemu ${ }^{40}$.

\section{POCZUCIE GODNOŚCI I HONORU W HISTORII}

W świecie idei panuje nieustanny ruch, dokonują się przeobrażenia w rozumieniu pojęć w ciągu dziejów, na co również zwracano uwagę w romantycznych dyskusjach. Te zmiany dotyczyły także poczucia narodowej godności. Zastanawiano się więc nad problemem, czy jest ono stałe, czy też jego pojmowanie zmieniało się na przestrzeni wieków. Z reguły podkreślano ścisły związek między poczuciem godności i honoru, a przeobrażeniami polityczno-społecznymi i umysłowymi, czyli ogólniej wiązano go z postępem. W ujęciu Karola Libelta pojęcia honoru i godności nie były znane w starożytnym świecie. Abstrakty te wypłynęły wraz „z podniesieniem się indywidualności ducha”, dając „koloryt żywy rycerskim i romantycznym wiekom". Człowiek musiał poznać w sobie szlachetną cząstkę swojej istoty, „uczuć ją na całej powierzchni żywota i wszystkich stosunków swoich". Honor i godność to w swej istocie pierwiastki germańskie, pojęcia pozostające w sprzeczności z wszelkiego rodzaju materializmem, zarówno w rozumieniu doczesnych

39 J. Słowacki, Dzieła, t. XI pod redakcją J. Krzyżanowskiego, Wrocław 1952, s. 290.

40 Mój sposób widzenia rzeczy, myśli i pomystów "Przegląd Naukowy Literaturze, Wiedzy i Umnictwu poświęcony" Warszawa 1844, nr 8-9, s. 282 
korzyści jak i fizyczności. Ich natura jest więc czysto duchowa, utrzymująca się głównie poprzez wiarę i tradycję ${ }^{41}$.

Jak podkreślano, w różnych okresach historycznych poczucie godności narodowej rozkwitało, to znowu przeżywało wyraźne upadki. Na przykład w XV i XVI wieku Polacy stojący na straży Europy, przodujący w rozwoju instytucji wolnościowych, mieli wysokie poczucie zbiorowej godności, przynajmniej w obrębie narodu szlacheckiego. Natomiast jako okres upadku godności narodowej Polaków najczęściej wymieniano czasy panowania Augusta II i Augusta III. Jedną z nadrzędnych przyczyn tej sytuacji była niewola chłopów, system pańszczyźniany, upadek obyczajów i ogólny regres w rozwoju społecznym i kulturalnym ${ }^{42}$.

W bardziej krytycznych ujęciach ograniczano okres narodowej chwały w zasadzie do panowania kilku lub nawet jednego władcy. W polskich dziejach "tylko jeden Bolesław Wielki świecił rzetelną wielkością, rozległością pomysłu politycznego - on to w pierwiastek słowiański umiał wszczepić zasadę zachodnio-europejską". Ponadto, dbając o narodową godność, umocnił on stan rycerski w ten sposób, iż każdy niezależnie od urodzenia, kto czynem udowodnił swoją szlachetność i honor, mógł stać się pełnoprawnym członkiem tej uprzywilejowanej grupy. Gdyby powyższe zasady zostały utrzymane, Polacy jako naród przetrwaliby w wielkim blasku chwały. Wraz z ich porzuceniem nastąpił stopniowy upadek narodowego ducha i godności ${ }^{43}$. Podobny pogląd prezentował K.B. Hoffman, gdy twierdził, że za czasów Bolesława Chrobrego godność narodu sięgnęła szczytu, zwłaszcza po zjeździe gnieźnieńskim, gdy cesarz niemiecki wyrzekł się na rzecz polskiego władcy misji polityczno-apostolskiej względem Słowian, co w konsekwencji zaowocowało nie tylko koroną monarszą, ale i tytułem króla ludów słowiańskich ${ }^{44}$. Natomiast do ponownego odrodzenia poczucia narodowej godności po latach upadku doszło dopiero u schyłku XVIII wieku, konkretnie w czasach Sejmu Wielkiego, gdy dla podniesienia godności zbiorowej próbowano przeprowadzić stosowne reformy, a najznamienitszym przykładem zabiegów $w$ tej kwestii było uchwalenie ustawy majowej.

W ujęciu szerszym, europejskim dostrzegano także okresy czy konkretne wydarzenia, które miały znaczący wpływ na upadek godności człowieka i narodów w uniwersalnym wymiarze. Adam Mickiewicz wskazywał na zmiany mentalnościowe, które dokonały się w Europie po wojnie trzydziestoletniej, gdy upadek moralny na skutek przyjęcia nowych zasad stał się bardziej widoczny. Po traktacie westfalskim w poglądach i umysłach społeczeństw doszło do głębokich przewartościowań, a przyjęte zasady wytyczyły kierunek nowoczesnej polityce europejskiej. Nie ma już mowy o poszanowaniu godności narodów, a „pomiatanie człowiekiem”, „pomiatanie opinią publiczną", egoizm, interes terytorialny, a zwłaszcza "siła materialna powołana na najwyższego sędziego we wszystkich sprawach" zawładnęły europejskim światem. Na tym tle Polska ukazywała się politykom europejskim jako „jakaś osobliwość”, "staroświecki przesąd rzetelności chrześcijańskiej”45.

W refleksji romantycznej wiele pisano o powołaniu jednostek, grup i narodów w ludzkości. W tym kontekście zbiorowa godność ściśle wiązała się z przeznaczeniem danej wspólnoty w dziejach, z wypełnianiem posłanniczej misji. Jak podkreślał Karol L. Szyrma, godność uczonych czy, szerzej, każdego człowieka zależy od istoty i przeznaczenia róż-

41 K. Libelt, O postannictwie dziejowem narodów, "Przegląd Naukowy Literaturze, Wiedzy i Umnictwu poświęcony", Warszawa 1844, t. 1, nr 3 i 4, s. 93.

42 "Nowa Polska" Warszawa 1831, nr 101.

43 "J. G., Sprawa polska w obecnej chwili, "Jutrzenka” nr 51 z dnia 29 maja 1848, s. 211.

44 K.B. Hoffman, dz. cyt., s. 23.

45 A. Mickiewicz, Literatura Stowiańska, kurs I, wykład XLI, [w:] Dzieła, t. 8, oprac. J. Maślanka, Warszawa 1998 , s. 590-591. 
nych ich powołań. Ta myśl dotyczy także poszczególnych narodów46. Najogólniej rzecz ujmując, realizowanie określonych celów oznaczało zachowywanie godności, natomiast rezygnacja z misji posłanniczej jej nieuchronny upadek. Przyswajanie i rozpowszechnianie oświaty zachodniej i obrona Europy przed zalewem barbarzyńskiej Azji jako nadrzędne zadania posłannictwa polskiego narodu w gronie oświeconych narodów europejskich było wiernie przez Polaków wypełniane. W tym kontekście naród polski zachował przez całe swoje dzieje narodową godność i honor.

Gorliwi zwolennicy idei postępu przewidywali dalszą ewolucję pojęcia godności, którego rozumienie będzie się zmieniać w zależności od warunków i stopnia rozwoju ludzkości. W każdym narodzie istnieje zespół pojęć i uczuć, które tworzą ich właściwość, ogólną cechę różniącą wspólnotę od innych zbiorowości. Nadrzędną potrzebą każdego narodu jest rozwijanie własnego wzorca postaw, zachowań, wartości. To potęga umysłowa wspólnoty. Jednocześnie zmiany w widzeniu pojęć następują nieustannie. Powtarzano za popularnym pisarzem francuskim markizem A. de Custine, że w czasach współczesnych dawne wyobrażenie zbiorowego honoru i dumy coraz częściej jest zastępowane poczuciem obowiązku i humanitaryzmu. Jak podkreślano, ta dostrzegalna zmiana $w$ rozumieniu pojęć dotyczy generalnie narodów posiadających własne niezależne państwa, a wówczas poczucie godności wiąże się z obywatelstwem. Narody pozbawione własnej organizacji politycznej miały dawne, w swej istocie niezmienne wyobrażenie zbiorowego honoru i dumy.

Jeszcze inaczej przedstawia się sytuacja narodów, które stosunkowo niedawno utraciły własną państwowość -- wówczas pamięć poczucia obywatelskiego pozostaje nadal żywa. Naród zniewolony o wielowiekowej państwowej tradycji funkcjonuje właśnie dzięki sile ożywczej wyrobionych idei, uczuć i wartości, a mimo chwilowego poniżenia dzięki nim właśnie z czasem, jak przewidywano, nastąpi odrodzenie. Jeden z publicystów periodyku "Zjednoczenie" twierdzit, że pojęcie obywatelskiego obowiązku wyrobiło się w języku polskim w zamierzchłej przeszłości i mimo upadku państwa nadal ściśle określa narodowe przymioty. Przed 1795 rokiem obywatelem kraju był tylko członek stanu szlacheckiego obdarzony określonymi cnotami politycznymi jak równość, niepodległość, wolność osobista, ale i moralnymi takimi, jak otwartość, bezinteresowność czy hojność. Większość wspólnoty pozostawała jednak poza obywatelstwem. Dawny szlachcic wybrany na urząd pełnił go z poczucia interesu wspólnego, bez widoków materialnej korzyści. Pojęcie godności ściśle łączyło się więc z niekwestionowanym przywiązaniem przodków do „obywatelskiej posługi, do obywatelskiego poświęcenia”. Zatem działać po obywatelsku to nie tylko myśleć, ale i czuć w ten sposób. Utrzymywanie tego wyobrażenia przodków, pielęgnowanie podobnych postaw i uczuć jest więc nadrzędnym zadaniem współczesnych Polaków w dziele ratowania i utrzymania narodowej godności, to "odziedziczony obowiązek". Innymi słowy, dbanie o narodową godność jest nie tylko związane z zachowywaniem narodowościowych znamion, polskiej mowy czy obyczajów. Jak podkreślano, należy także myśleć i działać w duchu, w jakim myśleli i działali przodkowie. W tym konserwatywnym z gruntu poglądzie przeszłość nie jest rzeczą minioną, przeciwnie, jej przymioty, szlachetne uczucia odżywają i stopniowo łączą z postępem czasów najnowszych ${ }^{47}$.

46 „Przemowa K.L. Szyrmy o powołaniu uczonych i przeznaczeniu stanu nauczycielskiego”, „Pamiętnik Umiejętności Moralnych i Literatury", Warszawa 1830, t. 3, s. 336.

47 Obywatelstwo, „Zjednoczenie. Dziennik narodowości poświęcony”, 1831, nr 15, s. 60-62. 
W polskiej myśli romantycznej poczucie godności narodowej - ta, jak ją nazywał Stefan Buszczyński, „najpiękniejsza cząstka istoty człowieka"48 - w najogólniejszym wymiarze ściśle wiązało się z ideą wolności, zagrożonej zarówno ze strony czynników zewnętrznych (wrogie działania innych państw i narodów), jak i w kontekście wewnętrznym (poprzez nadmierne umiłowanie własnej narodowości, uleganie materializmowi, postawę egoistyczną, ale także pogwałcenie praw sprawiedliwości i równości społecznej). Godność, honor, miłość ojczyzny to wartości, o których należy nieustannie przypominać, pielęgnować je i dbać o ich jak najszersze upowszechnienie w narodowej wspólnocie. Zwracano także uwagę na ścisłe związki, jakie zachodzą między godnością zbiorową a tą indywidualną, jednostkową oraz na swoistą ewolucję pojęcia godności w czasie i przestrzeni.

ON THE NOTION OF NATIONAL DIGNITY IN POLISH ROMANTIC THOUGHT

\section{Summary}

National dignity is one of principal notions that helps define fundamental ideas and aims of nationalism. The author of the article analyzes the Polish thought of the first part of the 19th century, presenting the diversity of views. Historically, national dignity was believed to represent group value and being proud of belonging to one's own nation, of its character and destiny within humanity. National dignity was an inalienable right and value closely connected with vital aspirations of a national community, with the ideal of freedom seen in the context of endangerments both from the outside (e.g., hostile actions of other states and nations), and from the inside (e.g., excessive love for one's own nation, materialistic approaches, selfishness, but also as threats that arise via injustice, and the absence of social rights and equality). Dignity, honor, love of one's motherland are values that we should constantly recall and at all times care for and propagate within a national community. In the article, special attention has also been paid to the way the older Polish thinkers presented the close relationships between collective dignity and individual dignity, as well as to the fact that the title notion has undergone a specific evolution in time and space.

Keywords: Romantic thought, national dignity, values, belonging

48 S. Buszczyński, Obrona spotwarzonego narodu..., s. 107, 108. 